\title{
Udział kobiet w edukacji i opiece na łamach tygodnika „Bluszcz” w latach 1918-1939
}

Prasa dwudziestolecia międzywojennego w Polsce stanowi wciąż niewyczerpane zasoby informacji także $w$ dziedzinie oświaty i wychowania. Sięgając do tytułów, które „od zawsze” budziły zainteresowanie czytelników oraz historyków czasopiśmiennictwa, mamy świadomość pewnego wyzwania, które niesie ze sobą każda próba odczytania ich po raz kolejny. Ale też za każdym razem przyjemność poznawania - studiowania na nowo materiałów, po które sięgali dawniej i całkiem niedawno specjaliści prasoznawcy. Dla historyka wychowania wykorzystanie prasy jako źródła wiedzy o wychowaniu i kształceniu młodego pokolenia oznacza pokonywanie różnorodnych ograniczeń oraz barier wynikających z samej istoty prasy jako mniej lub bardziej wiarygodnego materiału z uwagi na autorów przekazu oraz rzetelność - wiarygodność samej informacji. Inaczej mówiąc, konieczne jest przestrzeganie zasady komplementarności i wyczerpalności źródeł. Przystępując do charakterystyki pisma tygodniowego, należy uwzględnić specyfikę zawartości poszczególnych roczników, w tym fotografii, portretów, rysunków, grafik, a nawet nekrologów i wspomnień pośmiertnych rozproszonych w wielu zeszytach, wzbogacających wiedzę o postaciach bardziej i mniej znanych, niekiedy zaskakujących, gdyż odkrywających nieznane fakty z biografii lub dziejów instytucji'. Jakie trudności napotyka badacz historii wychowania gromadzący materiał źródłowy na podstawie prasy? Takie pytanie postawiła kilka lat temu Alicja Kicowska w artykule Prasa jako źródło w badaniach historyczno-edukacyjnych (wybrane problemy)2. Odpowiedź przywołanej w tym miejscu autorki brzmiała, że dotyczą one „oceny

* Dr, Zakład Dydaktyki Ogólnej i Wczesnej Edukacji, Instytut Edukacji Szkolnej, Wydział Pedagogiczny i Artystyczny, Uniwersytet Jana Kochanowskiego, 25-029 Kielce, ul. Krakowska 11.

${ }^{1}$ G. M i c h a I s k i, Źródła do badań biograficznych w historii wychowania, [w:] Konteksty i metody w badaniach historyczno-pedagogicznych, red. T. J a ł m u ż n a, I. M i c h a I s k a, G. M i c h a I s k i, Kraków 2004, s. 171-182.

${ }^{2}$ A. K i c o w s k a, Prasa jako źródło w badaniach historyczno-edukacyjnych (wybrane problemy), [w:] Konteksty i metody..., s. 193-199. 
analizowanych tekstów prasowych w kontekście całokształtu poglądów i działalności ich autorów; tendencyjnego fałszowania opisywanych faktów [...] lub autorskiego - subiektywnego opisu zdarzeń". Mając na względzie powyższe zastrzeżenia sięgnęłam po bardzo znany i popularny tygodnik kobiecy zatytułowany „Bluszcz”, zaliczany przez prasoznawców do kategorii wydawnictw zarówno społecznych, jak i literackich. Pojęcie „prasa” w odniesieniu do wybranego przeze mnie tygodnika (opatrywanego przez wydawców w podtytuły: tygodnik literacko-kulturalny, tygodnik kobiecy, tygodnik społeczno-kulturalny) jest uzasadnione, bowiem „Bluszcz” zgodnie z definicją, czym jest prasa „odzwierciedlał wszechstronnie rzeczywistość, zwłaszcza aktualne procesy i zdarzenia polityczno-społeczne, gospodarcze, naukowe, kulturalne i inne"3. Najczęściej tygodnik ten wymieniano wśród innych tytułów prasy kobiecej jako pismo niecieszące się zbytnią popularnością z powodu „wysokiego" poziomu artykułów, w domyśle adresowane do postępowych i wykształconych, wyemancypowanych czytelniczek, a nie jako pismo dla wszystkich odbiorców chętnie przez wiele osób prenumerowane, kupowane i czytane. Dotychczasowi badacze pisma „Bluszcz”, szukając informacji o jego nakładzie podawali w przybliżeniu liczbę 10000 egzemplarzy, gdyż w samym tygodniku wysokości nakładu nie zamieszczano. Nie unikano też porównań z innymi periodykami tego okresu, szukając odpowiedzi na pytanie jak z prawdopodobną ilością nakładu pismo wyglądało na tle innych tygodników dwudziestolecia międzywojennego. Przeciętne nakłady dla tygodników, jak ustalono, nie przekraczały 5000 egzemplarzy, dla czasopism naukowych i fachowych - nie przekraczały 1500 egzemplarzy, jeśli chodziło o kwartalniki oraz 4500 sztuk w przypadku miesięczników ${ }^{4}$. Także cena jednego egzemplarza budziła zainteresowanie, tak więc podawano ją, ale bez dodatkowych wyjaśnień czy 1 zł $60 \mathrm{gr}$, a potem 1 zł $40 \mathrm{gr}$ - taka była cena „Bluszczu” w 1925 r. - to dużo na tle innych periodyków czy mało (był okres, że pismo staniało do 1 zł a nawet do $50 \mathrm{gr}$ - w 1939 r.). Przykładowo, inny periodyk „Tygodnik Przemyski" w analogicznym okresie kosztował 1 zł $20 \mathrm{gr}$, nie jest więc pewne, czy cena „Bluszczu” stanowiła zachętę do prenumeraty bądź jednostkowego zakupu czy raczej zniechęcała ${ }^{5}$. Biorąc pod uwagę ceny podstawowych produktów oraz przeciętne zarobki w Drugiej Rzeczypospolitej, można sądzić, że cena egzemplarza powyżej 1 zł i $50 \mathrm{gr}$ była dość wysoka, a z kolei niska cena - $50 \mathrm{gr}$ - nie pokrywała w pełni kosztów wydawnictwa ${ }^{6}$.

${ }^{3}$ Encyklopedia wiedzy o prasie, Wrocław 1976, s. 168; Prasa polska w latach 1864-1918, red. Z. K m i e c i k i in., Warszawa 1976.

${ }^{4}$ A. P a c z k o w s k i, Prasa polska w latach 1918-1939, Warszawa 1980, s. 310. Nie jest moim zdaniem w pełni uzasadnione porównanie „Bluszczu” z pismem „Moja Przyjaciółka”, które pojawiło się w latach 30. i miało w 1938 r. rekordowy nakład 100000 egzemplarzy. Por. A. P a c z k o w s k i, Prasa..., s. 251.

${ }^{5}$ J. C h wa sty k-K o walc z y k, „Bluszcz” w latach 1918-1939. Tematyka społeczna oraz problemy kultury $i$ literatury, Kielce 2003; K. Dormus, Problematyka wychowawczo-oświatowa w prasie kobiecej zaboru austriackiego w latach 1826-1918, Warszawa 2006; A. P a c z k o w s k i, Prasa...; W. P i s a r e k, Analiza zawartości prasy, Kraków 1983.

${ }^{6} \mathrm{~W}$ Warszawie przeciętne wydatki rodziny pracowników umysłowych na gazety i książki wynosiły 88,80 zł rocznie. $W$ rodzinach o dochodzie poniżej 150 zł miesięcznie -40 zł rocznie. Por. A. P a c z k ow s k i, Prasa..., s. 22. 
Zgodnie ze współczesną teorią komunikacji społecznej media są przeznaczone do pośredniczenia w zakresie przekazu między nadawcą a odbiorcą. Tak więc postawmy kilka pytań o treść tygodnika „Bluszcz”: Kto komunikował się z kim? W jakim celu? W czyim interesie?

Sformułowane powyżej podstawowe problemy dotyczące prasy jako źródła i środka komunikacji społecznej posłużyły w niniejszym szkicu jako swoiste drogowskazy w wędrówce po zawartości kilkunastu roczników tygodnika „Bluszcz” w okresie jego ukazywania się w Drugiej Rzeczypospolitej. Dokładnie było to 19 roczników, bowiem pismo ukazywało się w roku 1918 - rocznik 52 (do numeru 41 jeszcze za zezwoleniem cenzury rosyjskiej, a od numeru 42 z 19 listopada 1918 r. w Polsce Niepodległej), a następnie z krótkimi przerwami w latach 1921-1939, zmieniając wydawców i skład redakcji, a także objętość, morfologię i estetykę wydawniczą. W omawianym okresie dwudziestolecia międzywojennego początkowo wydawcą była grupa kobiet zrzeszona w organizacji pod nazwą Koło Polek pod kierunkiem Konstancji Łubieńskiej, a później od 1924 r. spółka o nazwie „Bluszcz” kierowana przez Zygmunta Pierackiego (początkowo spółka potem Towarzystwo Wydawnicze „Bluszcz”) ${ }^{7}$. Pismo „Bluszcz” od początku jego ukazywania się zaliczano do pism tzw. kobiecych, związanych ściśle z rozwojem ruchu kobiecego na świecie i na ziemiach polskich początkowo pod zaborami, następnie w Polsce niepodległej ${ }^{8}$. W wyniku tego tak w starszych, jak i nowszych badaniach i opracowaniach czasopiśmienniczych przyjęta przez prasoznawców klasyfikacja czasopism doprowadziła do ulokowania „Bluszczu” na określonej „wyższej półce” i zatwierdzenia wcześniejszej opinii, że sięgają po nie głównie kobiety z wyższych sfer. Kobiety zamożne i mniej zamożne, szukające możliwości potwierdzenia swojej wartości oraz niezależności poprzez wymianę poglądów na forum publicznym (dział Nasza Mównica w „Bluszczu” w okresie międzywojennym), publikowanie utworów literackich, głównie pisanych przez „kobiety-autorki” lub do kobiet adresowanych, a także porównywanie własnych doświadczeń życiowych (głównie zawodowych) z obcymi. Nawet - co było wtedy nowością - przedstawianie bardzo interesujących relacji - reportaży z zagranicznych podróży z licznymi fotografiami, szkicami czy reprodukcjami. Co prawda, na łamach „Bluszczu” publikowali też autorzy-mężczyźni, historycy i politycy, pisarze i poeci, wśród nich Tadeusz Zieliński, Melchior Wańkowicz, Jan Brzechwa, Konstanty Ildefons Gałczyński, Stanisław Ryszard Dobrowolski, Jan Lechoń, ale podobno niezbyt chętnie to wspominali. Opinia, że analizowane przez nas pismo było konserwatywne, a w niektórych tylko okresach liberalne, nie jest odosobniona9 . „Bluszcz” pod redakcją Zofii Seidlerowej, która żyła w latach 1859-1919,

7 Z. S o k ó ł, Towarzystwo Wydawnicze „Bluszcz” Spółka z o.o. (1924-1939), „Studia Kieleckie” 2002, nr 2, s. 95-110.

${ }^{8}$ Z. Z a le s k a, Czasopisma kobiece w Polsce (Materiały do historii czasopism). Rok 19181937. Nakładem Wyższej Szkoły Dziennikarskiej w Warszawie 1938, s. 5. Por. też Działowy spis czasopism wychodzących w Polsce. Warszawa 1947-1954. Z. Seidlerowa opublikowała na łamach „Bluszczu” krótkie notatki o Mickiewiczu w roku 1905, 1906 i 1908.

9 Tamże, s. 104-105. Por. też J. C h w a s t y k-K o w a l c z y k, „Bluszcz”...; E. K r i s t a n o v a, Polskie pisma kobiece okresu 20-lecia międzywojennego (na przykładzie „Bluszczu”, „Kobiety wspótczesnej” i „Pani”), „Biuletyn Informacji Bibliotecznej i Kulturalnej”, R. XII, nr 15 (60), s. 5. 
a redagowała pismo od 1906 r. do 1918 r. zachowywał pewną rezerwę wobec żądań feministek, mimo że publikował materiały nie tylko o równouprawnieniu (prawach) kobiet, ale wyraźnie podkreślał, jak bardzo zmieniała się sytuacja i pozycja kobiety w rozpoczynającym się właśnie okresie niepodległej Polski. Podtytuł pisma był kilkakrotnie modyfikowany, ale prawie zawsze zachowywano informację, że jest to tygodnik dla kobiet (brak tej informacji tylko w rocznikach 1922-1923). W 1939 r. nastąpiła zmiana podtytułu na „Tygodnik Kulturalnej Rodziny”, co było w pełni uzasadnione $z$ uwagi na stałe i niezwykle starannie prowadzone rubryki repertuaru teatralnego, kinowego (świetne recenzje filmowe), koncertów muzycznych, nowości książkowych, czyli szerszego niż początkowo zakładano kręgu odbiorców. Świadczą o tym również wypowiedzi czytelników nadsyłane do redakcji.

Tygodnik „Bluszcz” należał do wydawnictw o bardzo odległym rodowodzie i nadspodziewanej żywotności, gdyż ukazywał się od roku 1865, z małymi przerwami, aż po rok 1939, no i w jakimś sensie ukazuje się nadal, gdyż 1 października 2008 r. został wznowiony jako „pismo miesięczne ilustrowane dla kobiet”, „pań w wieku 25-54 lata, posiadających wyższe wykształcenie, mieszkających w miastach". W 2010 r. po zmianie na stanowisku redaktora naczelnego, przekształcony został na miesięcznik kulturalny ${ }^{10}$. Pismo w połowie XIX w. założył Michał Gluckberg, wydawca, księgarz i drukarz, a jego pierwszą redaktorką była Maria Ilnicka (z domu Maykowska), publicystka, poetka, pisarka ${ }^{11}$. W latach 1918-1939 redakcją pisma kierowały: w 1918 r. - Z. Seidlerowa (zm. w 1919 r.), w latach 1921-1922 Stefania Podhorska-Okołów, w latach1922-1923 Sława Browińska, w latach 1923-1926 Wanda Pełczyńska, a w latach 1927-1939 ponownie Stefania Podhorska-Okołów. Towarzystwo Wydawnicze „Bluszcz” i Koło Polek patronujące temu tygodnikowi mieściły się w Warszawie przy pl. Zamkowym (Krakowskie Przedmieście 55). Sylwetki naczelnych redaktorek „Bluszczu” to przykłady biografii osób nietuzinkowych. Z. Seidlerowa, która doprowadziła pismo do rozkwitu w pierwszym dziesięcioleciu XX w. (w latach 1906-1907 było znane i cenione szczególnie jako tygodnik literacki), organizowała w swoim prywatnym mieszkaniu „bluszczowe czwartki”, na których zbierały się wybitne postaci ze świata kultury i sztuki. Gustaw Olechowski - felietonista i współpracownik „Bluszczu” tak opisał postać tej nowoczesnej redaktorki: „Pani Zofia jest uniwersalna: jedną ręką przyrządza pasztet, drugą pisze artykuł, pracuje od świtu do nocy i na wszystko ma czas"12. Zofia Seidlerowa aktywnie działała w organizacjach kobiecych czego dowodem był Zjazd Kobiet Polskich połączony z jubileuszem 40-lecia pracy Elizy Orzeszkowej, który zaowocował również specjalnym numerem „Bluszczu”13. Po jej śmierci (zmarła z powodu tyfusu) pismo zawiesiło działalność do $1921 \mathrm{r}$.

10 Od listopada 2010 r. w nowej edycji pisma redaktorem naczelnym jest Rafał Bryndal, publicysta i satyryk.

${ }^{11}$ Feminoteka, Muzeum Historii Kobiet, www.feminoteka.pl/muzeum.readarticle.php (dostęp: dnia 08.10.2011 r.).

12 Informacje pochodzą ze wspomnienia Anny Pechte, córki Zofii Seidlerowej, zamieszczone na łamach „Stolicy” w 1962 r. Por. „Stolica” 1962, R. XVII, nr 10 (744), s. 24. W „Bluszczu” w 1935 r. ukazały się dwa ocalałe listy Elizy Orzeszkowej z licznych pisanych przez nią do Z. Seidlerowej. „Bluszcz” [dalej: B], 14 XII 1935, nr 51/52, s. 26-28.

13 B, 9 VI 1907 r. 
W okresie Drugiej Rzeczypospolitej pod kierunkiem S. Podhorskiej-Okołów, literatki i dziennikarki, która redagowała „Bluszcz” w latach 1921-1922 oraz 1927-1939, pismo osiągnęło po raz kolejny bardzo dobry poziom publicystyczny ${ }^{14}$. Praca w charakterze publicystki „Bluszczu” i obowiązki na stanowisku naczelnej redaktorki nie były łatwe do pogodzenia. Zmienił się dwukrotnie właściciel tygodnika „Bluszcz”. Tygodnik, który został przejęty początkowo przez Koło Polek (1921-1924), a następnie przez Towarzystwo Wydawnicze „Bluszcz” (1924-1939), de facto spółkę wydawniczą (czyli inicjatywę obliczoną na zysk), był zapewne przedmiotem zabiegów oszczędnościowych, o czym świadczy bardzo skromna szata graficzna, kiepski papier, ubogie okładki. Tak więc, kierując tym pismem, trzeba było umiejętnie połączyć interesy materialne nowych właścicieli wydawnictwa $z$ własnymi aspiracjami ${ }^{15}$. Wydaje się, że dobra opinia o piśmie to zasługa redaktorki naczelnej Stefanii Podhorskiej-Okołów, która wytyczyła kilka kierunków rozwoju tygodnika, powierzając mu szczególną misję propagatora kształcenia i dokształcania kobiet, podejmowania przez kobiety pracy zawodowej i odnoszonych przez nie sukcesów, a równolegle nowej ważnej pozycji kobiety w gospodarstwie domowym jako żony, matki, wychowawczyni dzieci. O tym świadczy m.in. cykl „Kobieta w świecie i w domu”, a później „Biblioteka Wychowawcza Dziecka i Matki”, która była wydawana przez Towarzystwo Wydawnicze „Bluszcz” w latach 1929-1932, redagowana przez Antoninę Dembińską od 1930 r. i popularyzowana na łamach pisma. Towarzystwo „Bluszcz” opublikowało 22 tomy tej serii.

Tygodnik realizował w okresie Drugiej Rzeczypospolitej misję popularyzacji czytelnictwa w środowisku wykształconych i mniej wykształconych kobiet, a także wśród dzieci i młodzieży. W Warszawie powstała wówczas pierwsza biblioteka dla dzieci przy bibliotece publicznej na ul. Koszykowej, wzorowana na belgijskich bibliotekach dziecięcych, do której zapisywano przeważnie dzieci ze szkól powszechnych w wieku od siedmiu do czternastu lat. Niech przykład Warszawy zachęci prowincję - pisano - bo im „lepiej będziemy dzieci wychowywać tym lepszych obywateli kraj zyska”16. Znajdujemy w „Bluszczu” pochwałę dla pedagogiki bibliotecznej oraz porady, jak czytać i propagować czytelnictwo wśród młodzieży i dorosłych, zestawienia bibliograficzne różnych wydawnictw, a w 1933 r. (numer 47 z listopada) jeden z numerów specjalnych o charakterze

14 PSB, t. 23, 1978, s. 686-687. Stefania Podhorska-Okołów (1884-1962) nauczycielka historii i literatury, używała wielu pseudonimów literackich, była autorką felietonów, recenzji, szkiców o pisarzach, reportaży z podróży, przekładów powieści, po II wojnie światowej szkiców o życiu w stolicy. Bardzo ceniona i wielokrotnie nagradzana.

Wanda Pełczyńska z domu Filipkowska (1894-1976), posłanka na Sejm II RP 4. kadencji, oprócz „Bluszczu” redaktorka „Kobiety Współczesnej” i współredaktorka „Młodej Matki” (na podstawie http://bs.sejm.gov.pl (dostęp: 12.10.2011).

Sława z d. Płotnicka primo voto Brzostowska (1898-?1965) Browińska, z wykształcenia biolog, działaczka m.in. PCK, YMCA, RTPD, tamże.

15 Z. Sokół, Towarzystwo..., s. 105. Zofia Zaleska nazwała Towarzystwo Wydawnicze „Bluszcz” koncernem wydawniczym pism kobiecych. Dyrektorem spółki był w latach 1924-1936 Zygmunt Pieracki, w latach 1936-1939 ? Walewski. Por. Z. Z a l e s k a, Czasopisma kobiece..., s. 67.

${ }^{16}$ B 1926, nr 6, s. 161-162. 
monotematycznym, który został przeznaczony na publikację szeregu interesujących materiałów z dziejów książki i bibliotek oraz „dziwnego” zawodu - introligatorstwa $^{17}$.

S. Podhorska-Okołów skrupulatnie odnotowała w „Bluszczu” wszystko to, co dotyczyło sytuacji społecznej, politycznej i kulturowej kobiet w Polsce i na świecie, głównie wysoką pozycję kobiet w środowisku naukowym i ich awanse na arenie międzynarodowej. Kiedy jej dawna nauczycielka gimnazjalna (wówczas jeszcze rosyjskiego gimnazjum żeńskiego), a potem profesor Sorbony na katedrze sanskrytu i literatury indyjskiej dr Helena (z d. Grabowska) Willmanowa została zatrudniona na Uniwersytecie Jagiellońskim jako sanskrytolog, z entuzjazmem odnotowała ten fakt na łamach „Bluszczu”, podkreślając, że to wyjątkowy przypadek awansu naukowego najpierw w Paryżu („niechętnemu kobietom, a co dopiero cudzoziemkom”), a następnie w Krakowie („Pierwsza profesorka na Uniwersytecie Jagiellońskim"18).

Pismo sporo uwagi poświęciło Marii Curie-Skłodowskiej, która odwiedziła Warszawę po wielu latach zamieszkiwania we Francji, po raz pierwszy w 1921 r. i której „najgorętszym życzeniem [...] było aby w jej rodzinnej Warszawie powstał jak najprędzej instytut radowy"19. Po spotkaniu Curie-Skłodowskiej z delegatkami stowarzyszeń kobiecych na łamach „Bluszczu” podjęto starania na rzecz budowy nowoczesnego centrum badawczo-leczniczego. Zawiązano Komitet Daru Narodowego dla M. Curie-Skłodowskiej, pod protektoratem Michaliny Mościckiej i Aleksandry Piłsudskiej w styczniu 1930 r. rozpoczęto zbiórkę pieniędzy, a wkrótce także budowę instytutu ${ }^{20}$. Plac pod budynki przy ul. Wawelskiej ofiarował Uniwersytet Warszawski, a popierające inicjatywę Amerykanki przekazały na ten cel na ręce M. Curie-Skłodowskiej 50 tys. dolarów. „Wzniesiono już budynki lecznicy, pawilonu rentgenoterapii, pawilonu radu i pawilonu pracowni naukowych" - donosił z radością „Bluszcz”21. M. Curie-Skłodowska ofiarowała placówce gram radu, będący jej własnością, który stał się podstawą rozpoczęcia działalności centrum i pracy instytutu22. Po śmierci M. Curie-Skłodowskiej kilkakrotnie wspominano

17 Helena Radlińska (1879-1954) historyk wychowania, pedagog społeczny. Twórczyni m.in. pedagogiki bibliotecznej. Por. T. G u m u ła, Helena Radlińska jako historyk oświaty $i$ wychowania, [w:] Historia wychowania w XX wieku. Dorobek i perspektywy, red. T. G u m uła, J. K r a s u s k i, S. M a j e w s k i, Kielce 1998, s. 85-91.

${ }^{18}$ B, 4 I 1930, R. LXIII, nr 1, s. 12. Helena z Grabowskich (1870-1957) Willmanowa, sanskrytolog, od 1927 roku profesor UJ. Por. „Język Polski” 1957 (listopad/grudzień), nr 5.

${ }^{19}$ F. K r u s z e w s k a, Jak uczcić największą uczoną Polkę?, B 1930, R. LXIII, nr 2, s. 10-12.

20 Michalina Mościcka (1871-1932), żona prezydenta I. Mościckiego, czyli I Dama od 1926 r., Przew. Ligi Kobiet Polskich (istniejącej od 1913 r.) w latach 1920-1924, radna m. Lwowa, działaczka społeczna.

Aleksandra Piłsudska (1882-1963), działaczka PPS i POW, druga żona Marszałka J. Piłsudskiego, pozyskała fundusze m.in. na rzecz stowarzyszenia „Nasz Dom”, czyli zakładu dla sierot.

${ }^{21}$ F. Kruszewska, Jak uczcić... Kruszewska jako entuzjastka tego projektu napisała, że „Słuszne jest porównanie w tym wypadku Curie-Skłodowskiej z Kopernikiem” (s. 10). Inne artykuły: R. D a I b o r o w a, Pani Curie, B 1937, nr 47, s. 5; H. W i ę c k o w s k a, Kobieta w nauce, B 1938, $\mathrm{nr} 46$.

${ }^{22}$ Centrum Onkologii. Instytut im. Marii Curie-Skłodowskiej w Warszawie: 1932-2002, red. E. To w p i k, Warszawa 2002. Pierwszym kierownikiem Instytutu Radowego (dziś Centrum Onkologii w Warszawie) była siostra Marii Bronisława Dłuska. 
Uczoną, jej biografię i dorobek ${ }^{23}$, pisząc, że wcieliła w życie swoje „marzenie naukowe", a w Polsce stanął Jej pomnik niezniszczalny, owoc geniuszu - Instytut Radowy, który nazwała „najmilszą nagrodą”.

Również skromniejsze wydarzenia, jubileusze czy awanse naukowe odnotowywano na łamach pisma, przykładowo „70-lecie Pani Józefowej Hillarowiczowej", jednej z pierwszych w Polsce kobiet z wykształceniem uniwersyteckim, absolwentki nauk przyrodniczych Uniwersytetu w Genewie, autorki wielu prac naukowych, publicystki, zwolenniczki idei Fryderyka Foerstera ${ }^{24}$. Następny przykład to wywiad z Alicją Dorabialską pierwszą kobietą Profesor Politechniki Lwowskiej, współpracującą w czasie pobytu w Paryżu z M. Curie-Skłodowską, opublikowany w tygodniku kilkanaście lat później. Potwierdzał on możliwość awansu naukowego kobiet, ale i konieczność zmian w zakresie edukacji dziewcząt oraz przełamywania stereotypów co do „umysłowości kobiecej i jej ograniczeń”25.

Podkreślając sukcesy kobiet w zdobywaniu wyższego wykształcenia oraz przecieranie szlaków w zawodach męskich (pierwsza kobieta pilot, pierwsza kobieta weterynarz, farmaceuta, pierwsze sportsmenki: mistrzynie w bieganiu, narciarstwie, tenisie ziemnym, pływaniu itd.), akcentowano potrzebę wzajemnego wsparcia - solidarności kobiecej i poczucia dumy z bycia kobietą. Ruch solidarnościowy i zjednoczeniowy kobiet, który nasilił swoją działalność w okresie międzywojennym przybierał różne formy. Tylko w roku 1925 odnotowano w „Bluszczu” Zjazd Młodych Ziemianek, Zjazd Kobiet Wiejskich, Zjazd Narodowej Organizacji Kobiet, Zjazd Koła Polek, Komunikaty Biura Prasowego dla Spraw Kobiecych itp. W lutym 1930 r. w Pradze odbył się Zjazd Kobiet Słowiańskich, w którym aktywny udział brała delegacja z Polski ([Stefania - przyp. T. G.] Laudyn-Chrzanowska, Hanna Hubicka, Jadwiga Grudzińska), ale też delegatki z Serbii, Bułgarii, Słowenii, Słowacji oraz Rosjanki z emigracji26. W lipcu tego samego roku również w Pradze odbył się Kongres Federacji Kobiet z Wyższym Wykształceniem, który zgromadził delegatki z 40 krajów $^{27}$. Obok idei równouprawnienia, co w wielu krajach Europy stało się faktem, kobiety walczyły o skuteczną egzekucję swoich praw w życiu prywatnym i publicznym. Były to wszystkie grupy kobiet i tych wykształconych „z dobrego ziemiańskiego domu”, jak i z pozostałych sfer społecznych. W analizowanym tygodniku nie brakowało miejsca na sprawy kobiet wiejskich, kobiet w trudnej sytuacji życiowej, samotnych matek z dzieckiem, kobiet bezdomnych i wykolejonych. Kobiety wiejskie zasługiwały na jak najwyższe uznanie, gdyż jak donosił „Bluszcz”, intensywnie pracowały nie tylko we własnym gospodarstwie, ale też angażowały się w sprawy społeczne, np. w Wydziale Kół Gospodyń Wiejskich Centralnego Towarzystwa Rolniczego (gdzie niejako przy

${ }^{23}$ [b. a.], Jej wielka droga, B 1934, nr 28, s. 849-850; R. D a I b o r o w a, Pani Curie, B 1937, nr 47, s. 1101 (5); H. W i ę c k o w s k a, Kobieta w nauce, B 1938, nr 46.

${ }_{24}$ B 1930, nr 12, s. 14. Dokładna analiza prac F. W. Foerstera - patrz: D. K o ź m i a n, Chrześcijańska myśl społeczno-pedagogiczna Fryderyka Wilhelma Foerstera i jej recepcja w Polsce w latach 1918-1939, Szczecin 1996.

${ }^{25}$ S. O s iń s k a, Z wizytą u pierwszej kobiety, B 1934, nr 29, s. 5. A. Dorabialska pracowała na Politechnice Warszawskiej na stanowisku docenta, awans zaproponowano jej we Lwowie.

${ }^{26}$ Tamże, nr 9, s. 13-14 (z cyklu „Kobieta w świecie i w domu”).

27 Tamże, nr 32, s. 14. 
okazji wznowiły wydawanie pisma „Głos Kobiet Wiejskich”) ${ }^{28}$. Przy Warszawskiej Izbie Rolniczej powstała Komisja Pracy Gospodarczej Kobiet, do której weszły m.in. radczynie m. Lwowa Maria Karczewska i Eleonora Tarnowska. „Bluszcz” zachęcał młode kobiety mieszkające na wsi do uczestnictwa w oświacie pozaszkolnej, zamieszczając informacje o kursach uniwersytetu ludowego dla kobiet. Na przykład, w 1930 r. Uniwersytet Ludowy w Szycach (pow. Modlnica, woj. krakowskie) organizował od 15 marca czteromiesięczny kurs wiosenny dla młodzieży żeńskiej od 17 roku życia, o czym „Bluszcz” nie omieszkał powiadomić swoje czytelniczki29. Także Uniwersytet Ludowy im. S. Żeromskiego w Nałęczowie w domu na Pałubach prowadził kurs żeński dla dziewcząt powyżej 18 roku życia (bezpłatna nauka, a pobyt i wyżywienie 50 zł miesięcznie), który zaczynał się 1 kwietnia. Warto dodać, że pracę oświatową wśród kobiet prowadziły wtedy rozmaite samorządne organizacje, z których najstarsza z wymienianych w „Bluszczu” to Koło Gospodyń Wiejskich (działa od 1877 r., pierwsze koło założone we wsi Janisławice pod Skierniewicami przez Filipinę Płaskowicką). Z kolei druga - sporo młodsza - to Związek Pracy Obywatelskiej Kobiet, organizacja założona przez Izę Moszczeńską (od 1913 r. nosiła nazwę Liga Kobiet Pogotowia Wojennego, a po 1926 r. pojawiły się różne odmiany tego stowarzyszenia, np. w 1928 r. powstał sanacyjny Związek Pracy Obywatelskiej Kobiet) ${ }^{30}$.

Praca zawodowa kobiet była tematem ważnym dla redaktorów i współpracowników pisma. Nowoczesne refleksje pedagogiczne „O wyborze zawodu” zamieściła na łamach „Bluszczu” Teodora Męczkowska, pisząc „Aby dobrze wybrać zawód, trzeba dobrze poznać własne upodobania, własne uzdolnienia [...] zbadać jakich uzdolnień i specyficznych własności umysłu i charakteru ten czy inny zawód wymaga"31. Badaniem uzdolnień zajmowały się pracownie psychologiczne, ale autorka tekstu postulowała organizowanie odczytów popularnych, w tym odczytów kierowanych głównie do rodziców. Ponadto wyrażała pogląd, że rady pedagogiczne szkół lub rady wychowawców powinny poważnie zastanowić się nad każdym uczniem, a potem zorganizować konferencje z całymi klasami oraz rozmowy z poszczególnymi uczniami. Można też przeprowadzić ankiety preorientacji zawodowej z całą szkołą w kolejnych klasach wśród uczniów i osobno wśród nauczycieli. T. Męczkowska podała tu przykład ankiety, którą przygotowała i przeprowadziła w 1923 r. w szkołach warszawskich doktor medycyny i profesor psychologii doświadczalnej Józefa Joteyko, jako pracowniczka Państwowego Instytutu Pedagogicznego ${ }^{32}$. Pierwszą część ankiety wypełniali uczniowie i uczennice ostatnich klas

${ }^{28}$ Tamże, nr 8, s. 13-14. „Głos...” zmieniony wkrótce na „Przodownicę” pod red. M. Karczewskiej.

29 Tamże, nr 9, s. 14; nr 13, s. 14 oraz dodatek do nr 30 „Nasza Mównica”; [b. a.] Jak porządnie pracują.

${ }^{30}$ W. T r o p a c z y ń s k a, Oświata pozaszkolna wśród kobiet, B 1930, nr 32, s. 1-2.

31 B 1925, nr 19, s. 467-469. Teodora Męczkowska - m.in. prezeska Stowarzyszenia Kobiet z Wyższym Wykształceniem (wówczas wizytatorka szkół żeńskich MWRiOP 1936 r.) zamieściła Zarys historii feminizmu polskiego na łamach kwartalnika „Komunikat” - pisma Zarządu Głównego Stowarzyszenia Kobiet z Wyższym Wykształceniem, nr 11 z 1937 r.

32 Biografia Józefy Joteyko to przykład kariery naukowej za granicą (Bruksela, Paryż, Lyon), a porażek w kraju (dwukrotnie odmówiono jej katedry na UW). Mimo to dorobek J. Joteyko jest imponujący: 262 prace drukowane, liczne funkcje w komisjach, pismach i wydawnictwach naukowych. Por. np. O. L i p k o w s k i, Józefa Joteyko - życie i działalność, Warszawa 1968. 
szkół powszechnych oraz ostatnich klas szkół średnich, a drugą nauczyciel i lekarz szkolny. Wysiłek wkładany we właściwy wybór zawodu miał zaowocować nie tylko dobrą pracą uczniów w szkole, trafnym wyborem zawodu, ale także zaowocować w przyszłości i ograniczyć rozmiary bezrobocia.

Pismo chętnie prezentowało pracę placówek oświatowych, w tym funkcjonowanie wielu nowych szkół. Szczególną satysfakcję przynosiły placówki uruchamiane na terenach, gdzie prowadzono pracę oświatową w zasadzie od podstaw, czego przykładem była Szkoła Rolniczo-Gospodarcza w Działdowie. Na trzymiesięczny kurs żeński otwarty w 1926 r. zapisało się 70 dziewcząt, a obawiano się, że w ogóle nie będzie chętnych. Początki były trudne, gdyż większość uczennic uczyła się wcześniej w szkole pruskiej, ale nie znały w ogóle alfabetu łacińskiego $^{33}$. Tygodnik wielokrotnie chwalił nowatorskie szkoły zawodowe dla dziewcząt, przykładowo świetnie prosperującą od 1920 r. Państwową Zawodową Szkołę Żeńską w Grodnie, w której na 3-letnim kursie przygotowywano dziewczęta do pracy w krawiectwie i bieliźniarstwie, a także rozwijano uzdolnienia artystyczne na zajęciach z tkactwa, bukieciarstwa lub zdobnictwa i przygotowywano do nowoczesnego prowadzenia gospodarstwa domowego. Szkołą kierowała Stanisława Mościcka. Inna inicjatywa pedagogiczna zasługująca na uwagę to początki udanej akcji preorientacji zawodowej w szkołach. Również w Grodnie, z inicjatywy dyrekcji Państwowego Gimnazjum im. A. Mickiewicza, zorganizowano dla rodziców cykl otwartych odczytów na temat wyboru zawodu, podkreślając znaczenie nie tylko rozmów z dzieckiem w domu, dyskusji z nauczycielami w szkole, ale też szeroko rozumianej informacji zawodowej dla dorastającej młodzieży ${ }^{34}$. Autorka tę notatkę zakończyła słowami „Oby inne szkoły (żeńskie też!) poszły za tym przykładem”. W tygodniku nie brakowało przykładów nowoczesnych modeli kształcenia i wychowania. Z nowatorskiej żeńskiej zawodowej placówki oświatowej, mającej piękne tradycje (istniejącej już od 1891 r. w Królestwie Polskim w Chyliczkach, 20 km od Warszawy, a wznowionej w 1919 r.), nadesłała sprawozdanie Maria Karczewska. W artykule - reportażu zatytułowanym Nowe prądy w technice gospodarczej, autorka zamieściła zbiór fotografii z zajęć szkolnych w kuchni, w ogrodzie, w przetwórni mleka, a także z konkursu sprawności gospodarczej uczennic kończących szkołę (pokaz wyrobu konfitur z wiśni, przetwórstwo mięsa, wypiekanie chleba). Prace te, oprócz szkolnej wystawki, pokazywane były na licznych wystawach krajowych, gdzie zdobywały nagrody i wyróżnienia. Obok nauki organizowano dla dziewcząt wycieczki do podobnych placówek w Czechosłowacji, Jugosławii, na Węgrzech oraz zapraszano uczennice z tych krajów z rewizytą. Absolwentki szkoły („Chyliczanki”) pracowały w różnych szkołach zawodowych jako nauczycielki i z powodzeniem prowadziły własne gospodarstwa domowe ${ }^{35}$. Redakcja pisma polecała też inne formy dokształcania adresowane głównie do młodych ludzi, np. roczne kursy zawodowe prowadzone w Warszawie od 1927 r. przy ul. Nowy Świat 19 dla

${ }^{33}$ B 1926, nr 4, s. 111.

${ }^{34}$ [b. a.], Czym chce być nasze dziecko, B 1930, nr 12, s. 14.

${ }_{35}{ }^{35}$ B 1930, nr 32, s. 15-16. Szerzej na ten temat m.in. T. G u m u ła, Działalność oświatowo-wychowawcza Cecylii Plater-Zyberkówny (1853-1920), „Kieleckie Studia Pedagogiczne i Psychologiczne", t. 11/1996, s. 167-173. 
wychowawców świetlic, internatów, opiekunów społecznych. Przyjmowano na te kursy kobiety i mężczyzn od 19 do 35 roku życia, po 6-tej klasie szkoły średniej, po maturze lub po seminarium nauczycielskim ${ }^{36}$. Dużą popularnością cieszyły się „Jedenastomiesięczne szkoły gospodarstwa wiejskiego dla dziewcząt", których w roku 1926 było na terenie kraju aż 20, a które proponowały w swym programie lekcje ogólnokształcące oraz do wyboru sześć grup zajęć praktycznych (hodowlane, porządkowe, kucharskie, pralnicze, krawieckie) ${ }^{37}$. Jeszcze szerszy zakres obejmował nurt oświaty pozaszkolnej od kursów dla analfabetów po kursy dla młodocianych oraz dorosłych: zawodowe, dokształcające, aktywizujące, o których szeroko wypowiadała się Zofia Iwaszkiewiczowa w wywiadzie dla „Bluszczu” zatytułowanym Kobiety na placówkach kulturalno-oświatowych (oświata pozaszkolna) ${ }^{38}$. W Krakowie niestrudzone Koło Pań Towarzystwa Szkoły Ludowej urządzało wykłady teoretyczne i praktyczne na przedmieściach miasta, a dla pań z inteligencji kursy naukowej organizacji pracy w gospodarstwie domowym ${ }^{39}$. Kraków był dumny także z Seminarium Gospodarstwa, czyli szkoły prowadzonej pod kierunkiem Marii Strassburgerówny. Co roku absolwentki tej szkoły znajdowały zatrudnienie jako wykwalifikowane nauczycielki. Wspaniały gmach, w którym mieściła się Państwowa Szkoła Zawodowa i Państwowe Seminarium Zawodowe (w Krakowie przy ul. Syrokomli, prawie na krakowskich Błoniach), przeżywał oblężenie z powodu olbrzymiego napływu kandydatek (kilkaset podań na kilkanaście miejsc). Oprócz tego w Krakowie przy ul. Pędzichów istniała miejska szkoła gospodarstwa domowego, dostępna dla dziewcząt kończących szkoły ogólnokształcące i kursy gospodarstwa domowego przy żeńskich szkołach powszechnych.

Aby nie poprzestawać na dość krytycznie traktowanym i odbieranym przez czytelniczki (przecież jesteśmy już w początkach XX w.!) nurcie zarządzania gospodarstwem hodowlanym, ogrodniczym lub domowym, „Bluszcz” wiele miejsca przeznaczał na sprawy wychowania dzieci z perspektywy praw rządzących rozwojem jednostki i społeczeństwa ${ }^{40}$. Warta uwagi i studiów nad jej zawartością jest zapewne „Biblioteczka Wychowawcza Dziecka i Matki”, wydawana przez „Bluszcz” od 1930 r., w której znajdujemy takie pozycje, jak Samodzielność i odpowiedzialność dziecka autorstwa I. Moszczeńskiej czy Rozwój rysunku u dziecka i jego kształcenie Stefana Szumana.

Nurt pomocy dziecku i rodzinie w świetle zawartości pisma „Bluszcz” okresu międzywojennego obejmował następujące zagadnienia :

- poprawa warunków nauki w szkole powszechnej, rozbudowa i remont szkół,

- opieka nad sierotami, głównie w rodzinach zastępczych i nowoczesnych „domach sierot”,

${ }^{36}$ [b. a.], Nie wystarcza chcieć, trzeba umieć, B 1930, nr 39.

37 B 1926, nr 8, s. 238-239. Szkoły te były prywatne, państwowe lub samorządowe.

38 B 1930, nr 18, s. 3-5.

${ }^{39}$ M. M o s s o c z o w a, Szkoły gospodarstwa w Krakowie, B 1930, nr 18, s. 24.

40 Maria Turzyma już w 1902 r. w piśmie „Nowe Słowo” pisała, że najważniejsze jest budzenie myśli kobiecej, bo „przeszkody największe pochodzą od samych kobiet”. Por. też. Z. Zaleska, Czasopisma kobiece w Polsce (Materiały do historii czasopism). Rok 1818-1937, Warszawa 1938, s. $109-110$. 
- wypoczynek i zdrowie dzieci w wieku szkolnym, wakacyjne i świąteczne przerwy w nauce,

- stowarzyszenia pomocy rodzinie, w tym stowarzyszenia zawodowe (np. Rodzina Policyjna),

- pomoc dzieciom zaniedbanym, porzuconym i resocjalizacja nieletnich.

Helena Boguszewska opisywała sytuację szkolnictwa w Łodzi, gdzie ogółem w 1926 r. w kartotekach szkolnych odnotowano 60000 dzieci, a dla wielu z nich brakowało miejsc w szkołach powszechnych i szkołach specjalnych. Niedobrze też wyglądała opieka nad małym dzieckiem, brakowało miejsc w żłobkach, a „podrzutki” najczęściej trafiały do zakładów wychowawczych prowadzonych przez zgromadzenia zakonne ${ }^{41}$.

Warunki życia i nauki w szkole dzieci wiejskich opisała Aura [Aurelia] Wyleżyńska, która odwiedziła szkołę w Moszczenicy. Miejscowość Moszczenica (dziś sołectwo i dzielnica w obrębie miasta Jastrzębie-Zdrój), która liczyła wtedy 2000 mieszkańców, potrzebowała szybkiego działania władz szkolnych, a także publicznego wsparcia na rzecz budowy nowej szkoły. Pomimo starań dyrektora [Ludwika - przyp. T. G.] Drozińskiego i grona nauczycielskiego, bardzo miłej serdecznej atmosfery warunki nauki w szkole powszechnej w tej miejscowości były bardzo złe. Konflikt między mieszkańcami, kierownikiem szkoły a właścicielami gruntu, na którym stał budynek uniemożliwiał przeprowadzenie remontu, tak więc blisko 400 uczniów kształciło się w zdewastowanym, walącym się budynku, stanowiącym zagrożenie dla życia i zdrowia, bez podręczników i innych pomocy szkolnych $^{42}$. Niezbędne było odwołanie się do aktywności i ofiarności społeczeństwa. Na marginesie warto dodać, że wiele stowarzyszeń o charakterze lokalnym i krajowym współuczestniczyło w rozwiązywaniu problemów szkolnych, prowadząc zbiórki społeczne na rzecz remontów i budowy nowych szkół, pomocy materialnej ubogim uczniom, było to udziałem np. Towarzystwa Popierania Budowy Publicznych Szkół Powszechnych ${ }^{43}$.

Ważną kwestią podejmowaną przez redakcję pisma była sprawa opieki nad dziećmi sierocymi. H. Boguszewska w artykule „Nasz Dom”, opisała życie codzienne w placówce dla sierot prowadzonej przez Janusza Korczaka w Pruszkowie przy ul. Cedrowej 12, podkreślając, że to druga placówka dla ubogich dzieci tego typu ${ }^{44}$. Pierwsza mieściła się w Warszawie przy ul. Krochmalnej 22. H. Boguszewska wydobyła z pedagogiki Korczaka jej najważniejsze przesłania. Pisała: „Nie urabiać i przerabiać, a zrozumieć i porozumieć chcemy się z dzieckiem, pomóc do odrodzenia niewolniczej żebraczej jego duszy, do odrzucenia brudu, który przeniknął i opanował dzieci jako zaraza dorosłych"45. W domu sierot w Pruszkowie zachwycał

${ }^{41}$ B 1926, nr 10, s. 302-303; nr 11, s. 334-335.

42 A. W y l e ż y ń s k a, Zielony Śląsk, B,1933, nr 44, s. 8-9. Ludwik Droziński (1826-1936) jeden z wielu nauczycieli zasłużonych w walce o polską szkołę na Śląsku. Do 1922 r. nauka w szkole w Moszczenicy odbywała się w jęz. niemieckim.

${ }^{43}$ Por: S. W a I a s e k, Aktywność edukacyjna społeczeństwa polskiego w XIX i XX wieku, [w:] Orientacje i kierunki w badaniach historyczno-pedagogicznych, red. I. M i c h a I s k a, G. M i c h a I s k i, Łódź 2009, s. 244-245.

44 B 1926, nr 3, s. 69-70.

45 Tamże, s. 69. 
autorkę artykułu ład i współpraca dzieci pomiędzy sobą, sprawnie funkcjonujący system dyżurów, sąd koleżeński, „zakłady” prowadzące do poprawy zachowania w myśl idei Korczaka „Jeśli ktoś zrobi coś złego, najlepiej mu przebaczyć”. Postawy ludzi dorosłych oraz wpływy środowiska, w którym dzieci się wychowywały były wyraźnie widoczne w codziennych zachowaniach dzieci, a nie był to świat baśniowy. Jednak w skutecznym wychowaniu dziecka, podsumowała swoje refleksje Boguszewska, podstawą jest traktowanie podmiotowe - dziecko jest równorzędne wychowawcy - „bo dziecko, ale w pełni człowiek”. W kolejnej notatce „Bluszczu”, w dziale „Nasza Mównica”, informowano o „nowej instytucji pomocy dla sierot”, czyli o powstaniu w Warszawie w 1931 r. Komitetu Umieszczania Sierot w Rodzinie. Inicjatorka tego stowarzyszenia, nauczycielka państwowego kursu służby społecznej dla dziecka, była wizytatorka pomorskiego okręgu szkolnego, Wanda Szuman (w wielu miejscach podpisywała się Szumanówna), zarejestrowała komitet w Ministerstwie Pracy i Opieki Społecznej i otworzyła jego tymczasową siedzibę w Warszawie. Sama pracowała wtedy w gmachu, w którym prowadzono Kursy Służby Społecznej dla Dziecka na Nowym Świecie $)^{46}$. Komitet umieszczał dzieci w rodzinach małodzietnych, rzadko tylko i wyjątkowo w bezdzietnych, żyjących w bardzo dobrych warunkach. W $90 \%$ były to dzieci roczne i dwuletnie, wśród nich także te odbiegające od normy. W. Szuman - znakomity pedagog i skromny człowiek - spopularyzowała pomysł opieki rodzinnej nad sierotami najpierw na terenie Warszawy, a potem w całej Polsce ${ }^{47}$. Obok opieki nad dzieckiem równie istotne były problemy kształcenia i wychowania dzieci niepełnosprawnych, wielokrotnie opisywane na łamach „Bluszczu”. W 1930 r. ukazał się artykuł na temat Instytutu Głuchoniemych i Ociemniałych w Warszawie, który mieścił się w „prostym białym budynku" na Placu Trzech Krzyży. Instytutem kierował od 40 lat Aleksander Stefan Mamczarski (1896-1984), który kilka lat wcześniej, bo w 1917 r., opublikował monografię placówki w stulecie jej działalności. Na tle pracy Instytutu autorka artykułu nakreśliła szeroką problematykę dzieci kalekich. W wieku szkolnym, czyli od 7 do 15 roku życia, było wówczas w Polsce około 8000 dzieci głuchoniemych na ogólną liczbę 40000 głuchoniemych, aż 7000 dzieci pozostawało bez dostępu do szkoły. W Warszawie uczyło się tylko 163 dzieci, realizując program zwykłej szkoły powszechnej. Co prawda, od $1919 \mathrm{r}$. istniał oddział przedszkolny, a w $1934 \mathrm{r}$. planowano powołać zasadniczą szkołę zawodową, lecz była to kropla w morzu potrzeb. Barierą dla niektórych rodziców było wpisowe ${ }^{48}$. Obecnie, podsumowała autorka, czyli w 1930 r., ,jest w Polsce kilkanaście szkół dla głuchoniemych: dwie w Warszawie, jedna w Łodzi, 1. w Wilnie, 1. w Krakowie, 1. we Lwowie. Odrębnie prowadzi się trzy szkoły dla głuchoniemych Żydów. Najlepsza sytuacja panuje w Poznańskim. Stare szkoły są w Poznaniu i Kościanie, nowe w Wejherowie i Rybniku". Ale to stanowczo za mało w stosunku do potrzeb.

${ }^{46}$ B 1930, nr 28, s. 23-24.

${ }^{47}$ W 1934 r. Ministerstwo Opieki Społecznej prawnie usankcjonowało tę formę opieki nad sierotami. Szerzej na ten temat: M. J a m r o ż e k, Rodzina zastępcza jako środowisko wychowawcze, Kielce 2005, s. 20-23.

${ }^{48}$ J. P u t i a t y c z-Su ry n o w a, W wiecznej nocy $i$ ciszy, B 1930, nr 19, s. 3-4. 
Przykładem twórczych rozwiązań z dziedziny resocjalizacji nieletnich był Dom Dziewcząt na Okęciu, czyli zakład zamknięty dla dziewcząt prowadzony przez stowarzyszenie „Patronat nad więźniami”. Jego działalność opisała Stefania Podhorska-Okołów. Była to nowoczesna placówka, usytuowana na terenie dużej posiadłości (Fort VI), ogrodzona i dobrze strzeżona. Na terenie, pomiędzy pagórkami Fortu a domkami przedmieścia Warszawy (teren byłej żandarmerii rosyjskiej), rozciągał się ogród warzywny i sad, których wygląd dobrze świadczył o rezultatach pracy wychowawczej, gdyż wszystko było wykonane siłami wychowanek zakładu. Wnętrze domu było słoneczne, bowiem ściany, taborety, stoliki pomalowano na żółty kolor. Ozdobą placówki były liczne kwiaty doniczkowe, a całość - sale rekreacyjne i sypialnie, otoczenie budynku - zadbana i schludna. Wychowanki zakładu nosiły brązowe mundurki z białym kołnierzykiem, a skromny zestaw osobistych drobiazgów trzymały w kartonowych pudełkach pod łóżkami. Podhorska-Okołów zwróciła uwagę na regulamin zakładu, w którym nie było zakazów, a tylko wskazówki i uzasadnienia, nie było też terminów (pojęć) przestępstwo i kara. W domu dziewcząt przebywały dziewczęta "trudne”, ofiary złych warunków domowych, nieszczęśliwych miłości, zagnane w ślepą ulicę ${ }^{49}$. Autorka artykułu podkreślała, że dziewczynki walczą same ze sobą, o czym świadczą prowadzone przez nie dzienniczki czytane za ich zgodą tylko przez kierowniczkę placówki, a niektóre doświadczają gruntownej wewnętrznej przemiany. Zakład próbuje odbudować ich kontakty z rodziną, by po wyjściu z „domu” dziewczęta nie były samotne i bezdomne, a powrót do normalnego życia był faktycznie możliwy. Odbudowa i przebudowa charakteru wychowanek placówki odbywała się na drodze samodzielnie realizowanych i prezentowanych na scenie przedstawień teatralnych oraz improwizacji (może dziś powiedzielibyśmy - dramy). Inną ważną refleksję na temat konieczności organizowania opieki i wsparcia socjalnego dla ubogich dziewcząt i kobiet znajdujemy w artykule Brak ostatniego ogniwa ${ }^{50}$. Autorka podaje informacje o Misjach Dworcowych, które organizował i prowadził Polski Komitet do Walki z Handlem Kobietami i Dziećmi. Na warszawskich dworcach kolejowych: Głównym, Wschodnim, Gdańskim i Wileńskim misje prowadziły schroniska dla bezdomnych i bezrobotnych kobiet oraz dzieci. Organizowano noclegi, zapomogi, obiady, dopłaty do posiłków na stołówkach, udzielano informacji. Niestety, jak pisze autorka [H. C.?], zabrakło w tej pożytecznej społecznej akcji ostatniego ogniwa, czyli pracy dla bezrobotnych kobiet. Kolejna notatka w podobnej sprawie pokazywała dom noclegowy dla kobiet na warszawskiej Pradze. Pracownicy opieki społecznej przyjmowali tam wszystkie zgłaszające się kobiety. Do czytelników „Bluszczu” skierowano apel o pomoc w zakresie umieszczania dzieci i osób starszych w przytułkach, a do wszystkich, którzy mogli oferować pracę, choćby dorywczą, o zatrudnianie bezrobotnych ${ }^{51}$. Do tematyki misji dworcowych sięgnęła kilka lat później Hanna Koryzna, pisząc o misjach w Poznaniu i innych miastach Wielkopolski (Bydgoszcz, Leszno, Zbąszyń, Ostrowie).

\footnotetext{
${ }^{49}$ B 1933, nr 5, s. 8-10.

50 B 1926, nr 4, s. 132-133.

51 Tamże, nr 7, s. 196-197.
} 
Pierwsza misja w Poznaniu powstała już w 1910 r. nadal prowadzi, podobnie jak jej filie, noclegownie dla dziewcząt i kobiet oraz internaty ${ }^{52}$. Zbliżony charakter miały inne akcje opiekuńcze, na przykład opisana przez Stanisławę Osińską akcja pod hasłem „Ratujmy niemowlęta!” prowadzona przez zakład-schronisko dla samotnych matek przy ul. Spokojnej w Warszawie ${ }^{53}$.

Teoretyczne refleksje o wychowaniu młodzieży autorstwa Janiny Strzeleckiej pt. O nową formę ideałów młodzieży, opublikowano w listopadzie 1933 r. ${ }^{54}$ Strzelecka pisała: „Tyle wiemy o przeszłości, a tak niewiele o dniu codziennym, tyle i tak ciągle mówią nam o tym jak umierać za ojczyznę a tak mało o tem [!] jak w niej żyć, a przede wszystkim jak się uczyć żyć" [zachowana pisownia oryginału]. Apelowała do czytelników „dopomóżmy młodzieży w chodzeniu po ziemi!" We współczesnym wychowaniu należy opierać się na pierwiastkach emocjonalnych, budzić uczucia dumy i miłości ojczyzny, kształcić poczucie obowiązku wobec państwa i świadomego udziału w życiu zbiorowości. Niezbędne jednak okazuje się uzupełnienie tych romantyczno-historycznych funkcji wychowania o funkcje społeczne, o zadania praktyczne i zawodowe. Wielu autorów i autorek artykułów w „Bluszczu” przypominało rocznice historyczne (strajk szkolny, bitwę pod Wiedniem, powstanie listopadowe, dziesięciolecie pracy kobiet w Niepodległej Polsce i in.), eksponowało postać i rolę marszałka Józefa Piłsudskiego, z całości materiałów nie wyłaniał się niestety uporządkowany system pedagogiczny, raczej niespójny i nieuporządkowany obraz nowej koncepcji człowieka i jego roli w życiu publicznym ${ }^{55}$. Starania redakcji o wsparcie społeczne dla dzieci i młodzieży doprowadziły do publikowania kolejnych dodatków do „Bluszczu”, o czym poinformowano czytelników w 1933 r. Redakcja zapowiadała, że w 66 roczniku pisma od nowego 1934 r., raz na miesiąc ukazywać się będzie bezpłatny dodatek „Wychowanie i szkoła", poświęcony młodzieży w okresie szkolnym. Objętość pisma, zgodnie z zapowiedzią, zwiększono o 8 stron, znacznie poszerzono spis rzeczy, a w drugim dziale wyodrębniono następujące zagadnienia: wychowanie w domu i szkole (szkolnictwo nowoczesne Stoneczna szkoła w Alpach szwajcarskich, Praca domowa ucznia, Pierwszy dzień w szkole), kultura muzyczna, prawo w życiu codziennym, aktywność kobiet w samorządzie terytorialnym, wychowawcza rola rodziny, wychowanie przyszłych ojców, zdrowie i higiena ( $w$ tym walka z chorobami wenerycznymi $)^{56}$. Ogółem w „Bluszczu” znajdujemy wtedy 28 działów, łącznie z przepisami gospodarskimi, arkuszami wzorów, tablicami kroju, korespondencją z czytelnikami. Nie podniesiono kosztów prenumeraty, wręcz przeciwnie zachęcano czytelniczki do nabywania tygodnika, oferując nagrody za wierną prenumeratę

${ }^{52}$ B 1934, nr 22, s. 670-671.

53 Tamże, nr 28, s. 861-862.

54 B 1926, nr 44, s. 1-2.

${ }^{55}$ K. J a ku biak, Wychowanie państwowe jako ideologia wychowawcza sanacji: kształtowanie i upowszechnianie w periodycznych wydawnictwach społeczno-kulturalnych i pedagogicznych, Bydgoszcz 1994 oraz artykuły w „Bluszczu”: np. Z. S z m y d t o w a, O państwowym wychowaniu młodzieży, B 1926, nr 7, s. 195.

56 B 1934, nr od 1-30. 
w postaci wycieczek krajowych lub zagranicznych, tygodniowych lub weekendowych oraz książek. Nowoczesny model nauki języków obcych z zastosowaniem płyt gramofonowych i zestawu książek lansowano jako projekt walki z kryzysem i bezrobociem ${ }^{57}$.

Jak wcześniej wspomniałam, problematykę wychowania w rodzinie i w szkole na łamach „Bluszczu” podejmowano wielokrotnie. Najczęściej w formie apeli do wszystkich czytelników, do nauczycieli, do władz oświatowych, a nawet szerokiej opinii publicznej o realizowanie zadań wychowawczych w szkole, w rodzinie naturalnej, a także w środowisku opieki zastępczej ${ }^{58}$. Powtarzała się opinia, że szkoła uczy przedmiotów naukowych, a o wychowanie dziecka nie troszczy się zupełnie. Twierdzono, że braki w wychowaniu dziecka nie są tak rażące w młodszym wieku szkolnym, ale zaniedbania i błędy wychowawcze utrzymują się w okresie dorastania w szkole średniej i nadal są widoczne także na studiach wyższych. „A więc student prawa, ekonomii, chemii czy filozofii - pisano - nie wie gdzie trzymać ręce, kiedy wstać, kiedy siedzieć, jak się do kogo zwracać, jak obchodzić się z nożem i widelcem..." ${ }^{59}$. Wniosek jest oczywisty - wychowanie w szkole jest konieczne. Z zamieszczonych w „Bluszczu” materiałów wyłaniają się pedagogiczne ideały wychowawcze formułowane na podstawach psychologii doświadczalnej, filozofii i socjologii prowadzące od filantropii do wsparcia socjalnego oraz integracji społecznej. Badania podejmowane wówczas w naukach przyrodniczych prowadziły do współdziałania procesu wychowania i socjalizacji z rozwojem dziecka oraz konstruowania opisu badanej rzeczywistości jako teorii wychowania ${ }^{60}$.

W podsumowaniu staram się odpowiedzieć na pytania sformułowane na wstępie mojej wypowiedzi. Kolejne Redakcje tygodnika „Bluszcz” i ich współpracownicy komunikowali się z szeroko rozumianą opinią publiczną, dążąc do zainteresowania wszystkich czytelników sprawami życia dziecka, problemami młodego człowieka, wreszcie człowieka dorosłego, ale często bezradnego, bezdomnego i bezrobotnego, któremu potrzebna jest pomoc i wsparcie społeczne. Uzasadniona duma z rozwoju edukacji dziewcząt oraz nurtu kształcenia kobiet na wszystkich szczeblach oświatowych oraz odnoszonych przez nie sukcesów, nie przeszkadzała autorom publikacji w pragmatycznym podejściu do życia i wychowania młodego pokolenia. Popularyzacja stylu bycia modną panią domu, dobrze ubraną, dbającą o zdrowie własne i rodziny nie przeszkadzała także w dążeniach do aktywizowania kobiet na szerokim polu pracy społecznej, w czym również dostrzegam wartość analizowanej, z konieczności w dużym skrócie, zawartości tygodnika „Bluszcz”. Wydaje się, że misja społeczna i popularyzatorska pisma, mimo jego „kobiecego" i „literackiego” charakteru, została spełniona.

${ }^{57}$ Wielka akcja „Bluszczu”: Znajomość języków obcych najskuteczniejszą bronią kobiety w walce z kryzysem i bezrobociem, por. B 1934, nr 13, s. 401.

${ }^{58}$ S. M. R a c z k o w s k i, Szkoła a wychowanie, B 1930, nr 35, s. 22-23.

59 Tamże, s. 23.

${ }^{60}$ Por. W. L e ż a ń s k a, Wyjaśnianie w badaniach nad ideałami wychowawczymi Drugiej Rzeczypospolitej, [w:] Konteksty i metody..., s. 239-248. 